\title{
PRANATA HUKUM BERBASIS KEARIFAN LOKAL DALAM TATA KEHIDUPAN BERBANGSA DAN BERNEGARA
}

\author{
M. Hudi Asrori S \\ Fakultas Hukum Universitas Sebelas Maret \\ E-mail: hudisayuti@gmail.com
}

\begin{abstract}
In the transition system of modern life with all the phenomena that arise, at present, there are patterns of local wisdom and the life that holds fast to the principle ofl ifeis based on national values and moral, as well as discipline and obedience to the rules applicable in the environment. It exists in the Java community, especially in the Palace of Yogyakarta Sultanate. The conceptof national and state basis for a civilizednation Indonesia based on the persistence of religion and practice their religion according to their beliefs. Constitutionally this concept set for thin the Grundnorm Pancasila and Undang Dasar1945. Institutions based on local wisdom (Java) as aservicein the life of the nation is to up hold the principle of national unity Bhineka Tunggal Ika, the work ethic Tan Hana Dharma Mangrowa, based on the principle, Manunggaling Kawulo Gusti, Golong Gilig implemented, with the credo of service Nyawiji, Greget, Sengguh and Ora Mingkuh, to realize Hamemayu Hayuning Bawono as a primary goal in the life of the nation is prosperous, fairly and prosperous.
\end{abstract}

\section{A. Pendahuluan}

Fenomena kehidupan di awal abad ke-21 ini diwarnai dengan terjadinya reformasi di berbagai bidang kehidupan manusia. Pengaruh kemajuan di bidang teknologi dan informasi menyingkap tabir pembatas hubungan antar bangsa-bangsa di dunia dengan berbagai dampak positif maupun negatif bagi bangsa yang satu dengan bangsa yang lain. Tak terkecuali Negara Indonesia, dalam usianya yang ke 67 harus mengikuti tuntutan perkembangan kehidupan dunia internasional tersebut dengan segala konsekuensinya. Interaksi di antara bangsa-bangsa telah mempengaruhi pola hidup dan tuntutan-tuntutan baru yang selama ini tidak pernah diperolehnya. Namun demikian diantara dampak timbul, kiranya lebih banyak dampak negatifnya bagi tatanan kehidupan bangsa Indonesia. Pola kehidupan bermasyarakat beralih ke induvidualis, kehidupan musyawarah beralih ke tata cara vootingdan kontroversi, kehidupan konsumtif menjadi pilihan lebih utama. Perubahan pola dan tatanan kehidupan ini berakibat luas, diantaranya, korupsi seakan menjadi hal yang biasa, konflik dengan kekerasan menjadi model penyelesaian masalah, serta disiplin dan ketaatan terhadap peraturan menjadi lemah. Munculnya premanisme di tengah masyarakat seakan tak terkendali, akibatnya warga masyarakat hanya dapat melihat dan menjadi korban, tanpa tahu apa yang harus dilakukan dan kemana mencari tempat

Yustisia Vol.1 No.2 Mei - Agustus 2012 perlindungan. Hal inipun nampak pada lembaga kepemimpinan nasional, anggota wakil rakyat dan pejabat negara banyak terlibat korupusi, kekerasan sampai dengan tindakan asusila. Semuanya itu mengancam terhadap integritas dan identitas bangsa.

Di tengah proses peralihan pola dan tatanan kehidupan, saat ini, ternyata di dalam suatu lingkungan tata kehidupan bangsa Indonesia masih ada, hidup dan berkembang pola dan tatanan kehidupan yang memegang teguh prinsip kehidupan berdasarkan nilai-nilai kebangsaan dan budi pekerti bangsa, dan sangat disiplin dan taat terhadap peraturan yang berlaku di lingkungannya. Salah satu lingkungan kehidupan tersebut adalah lingkungan masyarakat Jawa, khususnya Keraton Kasultanan Yogyakarta. Prinsip hidup "hamemayu hayuning bawono" dengan kredo nyawiji, greget, sengguh dan ora mingkuh, merupakan kunci utama tetap terjaganya pola dan tatanan hidup yang mengedepankan kebersamaan, tata krama, budi pekerti dan ketaatan terhadap peraturan. Oleh karenanya sebagai suatu bukti pranatakehidupan berbangsa dan bernegara berbasis kearifan lokal yang melembaga kiranya perlu diungkap untuk dapat dipakai sebagai refleksi terhadap pola dan tata kehidupan bangsa Indonesia, saat ini.

Pranata Hukum Berbasis Kearifan... 


\section{B. Pranata Kehidupan Berbangsa dan Bernegara}

Pada dasarnya kebutuhan akan konsep pranata untuk memberikan kontribusi pemikiran terhadap berbagai permasalahanyang timbul di dalam penguatan nilai-nilai kebangsaan dan budi pekerti bangsa, serta peningkatan disiplin dan ketaatan terhadap peraturan, sangat mendesak. Kontribusi yang diharapkan dapat memberikan kontribusi pemikiran terhadap pengembangan ilmu hukum, khususnya mengenai konsep kearifan lokal dalam mengembangkan sumber daya manusia dengan pola dan tata kehidupan berbangsa dan bernegara.

Konsep pola dan tata kehidupan berbangsa dan bernegara berbasis kearifan lokal inilah yang diharapkan dapat memberikan kontribusi informasimengenai arti pentingnya mempertahankan pola dan tata kehidupan yang sudah ada dan hidup di lingkungannya sehingga terjaga integritas dan identitasnya. Selanjutnya dapat diperoleh model implikasi pola dan tata kehidupan, yang dapat memperkuat nilai-nilai kebangsaan dan budi pekerti bangsa, serta displin dan ketaatan terhadap peraturan.

Isu strategis yang dihadapi bangsa dan negara Republik Indonesia, saat ini, adalah rendahnya nilai-nilai integritas dan identitas nasional. Berkurangnya sikap dan rasa nasionalisme adalah sebagai akibat pengaruh globalisasi di segala sektor kehidupan berbangsa dan bernegara. Di samping itu, bersifat lebih mendasar, adalah dilakukannya perubahan-perubahan terhadap pola dan tata kehidupan berbangsa dan bernegara melalui amandemen Undang-Undang Dasar 1945, diaplikasikan ke dalam peraturan perundangan sebagai hukum positif yang berlaku dan mengikat seluruh bangsa Indonesia. Akibat dari perubahan tersebut bersifat positif dan negatif, namun akibat negatif nampak lebih dominan. Konflik dan perbedaan pendapat seakan hanya dapat diselesaikan dengan kekerasan, pelanggaran hukum menjadi kebiasaan, tata krama dan toleransi semakion jauh ditinggalkan. Fenomena ini terjadi di hampir semua lapisan masyarakat, sehingga secara sistemik akan melemahkan kualitas manusia/bangsa Indonesia yang berakibat tidak mempunyai daya saing dengan bangsa-bangsa lain.

Oleh karena itu sangat diperlukan adanya kajian terhadap fenomena ini dengan menggali kembali nilai-nilai integritas dan identitas bangsa Indonesia dari kearifan lokal yang berakar, hidup dan Yustisia Vol.1 No.2 Mei - Agustus 2012 berkembang di dalam kehidupan bangsa Indonesia itu sendiri. Salah satu bukti berupa data lengkap secara visual maupun dokumen terdapat di dalam lingkungan kehidupan Keraton Kasultanan Yogyakarta. Secara visual di dalam Keraton Kasultanan Yogyakarta masih terlihat pola dan tata kehidupan organisasi, tata kerja birokrasi, kedisiplinan dan ketaatan semua pihak terhadap pranata hukum. Sistem kerja antar lembaga dan permasalahan yang timbul di dalamnya diselesaikan secara santun dengan metode musyawarah sesuai tradisi yang berlaku turun temurun.

Pengkajian terhadap kearifan lokal dari lembaga adat yang ada di dalam Keraton Kasultanan Yogyakarta, kiranya tidak berlebihan, mengingat sejarah perjuangan bangsa Indonesia sampai kemerdekaan Negara Republik Indonesia tidak pernah lepas dari peran serta dan eksistensi lembaga kerajaan, di bawah kepemimpinan Sri Sultan Hamengkubuwana IX. Hal ini dilakukan sebagai upaya penguatan nilai-nilai kebangsaan dan budi pekerti bangsa, sehingga disiplin dan ketaatan terhadap peraturan dapat ditingkatkan. Bahwasanya model kearifan lokal dalam mengembangkan sumber daya manusia sudah ada di dalam kepribadian dan cita hukum bangsa Indonesia, yang dicontohkan oleh para pejuang dan pahlawan kusuma bangsa dengan ajaran yang bernilai luhur sejak dahulu kala. Namun saat ini sudah banyak ditinggalkan, bahkan sudah tidak diketahui oleh sebagian generasi muda penerus estafeta perjuangan kehidupan berbangsa dan bernegara Republik Indonesia.

\section{Eksistensi Pranata Hukum Dalam Kehidupan Berbangsa dan Bernegara}

Di dalam kehidupan berbangsa dan bernegara di jaman modern ini, pola perilaku dan tata kehidupan manusia diatur dengan suatu peraturan perundangan yang dibuat oleh lembaga yang berwenang. Peraturan perundangan dibuat secara tertulis dan merupakan peraturan formal. Secara normatif ketentuan-ketentuan di dalamnya merupakan hukum positif yang berlaku mengikat semua warga negara.

Hukum positif merupakan konsekwensi dari eksistensinya di dalam suatu sistem hukum. Descartes, merintis tradisi berpikir rasional dan atomistic (dengan cara memecah dan memilahmilah), dalam perkembangan disambut oleh Issac

Pranata Hukum Berbasis Kearifan...

195 
Newton, dengan melihat alam sebagai suatu institusi yang sistematis, mekanistis, linier dan deterministik. Pikiran Cartesian-Newtonian inilah yang kemudian mengilhami kaum positivis yang menghendaki agar hukum modern pun harus dipahami, digarap dan diselenggarakan secara sistematis, logis dan rasional. Menurut Hart (1972: 89-92), senantiasa ada hubungan erat antara institusi hukum dengan perkembangan organisasi masyarakatnya. Hubungan itu oleh Hart secara teoritis dideskripsikan sebagai bentuk-bentuk penginstitusionalan hukum, yang dimulai dari bentuknya yang paling sederhana sampai ke bentuk yang rumit, sesuai dengan perkembangan masyarakatnya.John Austin (Friedmann, Wolfgang terjemahan Muhammad Arifin, 1993), hakikat hukum terletak pada unsur perintah. Hukum adalah perintah penguasa. Hukum dipandang sebagai sistem yang tetap, logis dan tertutup. Dikatakan sebagai sistem "tertutup" karena hanya pihak penguasa sajalah yang dapat menentukan apa yang diperbolehkan dan apa yang tidak diperbolehkan. Penguasa, dengan kekuasaannya dapat memberlakukan hukum dengan cara menakut-nakuti dan mengarahkan tingkah laku seseorang ke arah yang diinginkannya.

Berpijak pada kajian hukum dalam bentuk peraturan perundangan terhadap kenyataan sosial bahwa, hukum sering dikatakan mempunyai "doublefaceted characters" (Cotterrell, 1984: 3) yang dapat diungkapkan dengan berbagai cara, yaitu hukum terdiri dari ketentuan-ketentuan yang seharusnya subjek legal berperilaku, dan pada waktu yang sama hukum merupakan suatu fenomena sosial yang hanya terjadi apabila ketentuan perilaku mempunyai beberapa efek terhadap cara orang-orang berfikir dan berperilaku. Apa yang dianggap keadilan atau ketidakadilan, kebijaksanaan atau efisiensi, signifikasi atau politik hukum bukan merupakan dasar untuk memahami hukum selama peraturanperaturan hukum dapat dinyatakan dengan jelas. Hanya ketika ketentuan-ketentuan hukum sulit untuk dipahami, ketika peraturan-peraturan tidak jelas atau aplikasinya terhadap suatu kasus baru menimbulkan keraguan, "unsur-unsur yang merupakan fenomena sosial dari hukum" harus dipertimbangkan. Unsurunsur fenomena sosial tersebut, salah satunya, adalah budaya hukum.

Negara Republik Indonesia menyatakan sebagai negara hukum. Hukum di sini diartikan sebagai hukum modern yang beraliran positivistik. Namun demikian substansial dari hukum di Indonesia berbasis kearifan lokal bangsa Indonesia. Hal ini tercermin dari sila-sila dalam Pancasila, yaitu Ke-Tuhan-an yang Maha Esa, Kemanusiaan yang adil dan Yustisia Vol.1 No.2 Mei - Agustus 2012 beradab, Persatuan Indonesia, Kerakyatan yang dipimpin oleh hikmah kebijaksanaan dalam permusyawaratan/perwakilan, dan keadilan sosial bagi seluruh rakyat Indonesia. Mencermati katakata di dalam kelima sila di atas, dapat diketahui bahwa kehendak para pendiri Negara Republik Indonesia adalah sangat arif dan berbudaya, artinya negara ini didirikan dengan cita-cita kesejahteraan lahir dan batin, yaitu berniat untuk ibadah kepada Tuhan Yang Esa, ditegakkannya peri kemanusiaan yang adil dan beradab, dengan mengedepankan persatuan berdasarkan permusyawaratan untuk mencapai keadilan sosial bagi seluruh rakyat Indonesia.

Prisip-prinsip bernegara dan berbangsa yang luhur tersebut dijabarkan di dalam UndangUndang Dasar 1945.Dengan demikian, pada dasarnya, Negara Republik Indonesia adalah negara hukum (Rechtsstaat) bukan negara kekuasaan (Maachtsstaat).Berdasarkan landasan konstitusional inilah semua kehidupan bernegara dan berbangsa, serta semua kebijakan yang ditentukannya, harus dilaksanakan berdasarkan hukum negara dalam bentuk peraturan perundang-undangan. Produk hukum yang dikeluarkan oleh negara melalui lembaga yang diberi kewenangan untuk itu oleh UndangUndang Dasar 1945 merupakan hukum negara. Dengan pola pikir seperti itu maka hukum negara merupakan peraturan perundang-undangan yang mempunyai bentuk formal dan bersifat yuridis normatif.

Tata cara pembuatan suatu peraturan perundang-undangan dilakukan berdasarkan hukum dasar negara dan peraturan perundangundangan yang telah ditetapkan. Tata cara tersebut meliputi tata susunan (hirarki) peraturan perundang-undangan yang telah ditetapkan dan proses pembuatan sejak pengusulan rancangan undang-undang sampai dengan ditetapkan dan disahkannya menjadi undang-undang. Suatu peraturan perundang-undangan mempunyai kekuatan berlaku dan mengikat, bagi warga negara berlaku asas asas iedereen wordt geacht de wet te kennen

Semua produk peraturan perundangundangan merupakan hukum negara yang mempunyai kekuatan berlaku dan mengikat semua bangsa negara Republik Indonesia tanpa kecuali.Sejarah mencatat bahwa, sejak merdeka tanggal 17 Agustus 1945, Negara Republik Indonesia telah megalami dua kali perubahan mengenai kewenangan pembuatan peraturan perundang-undangan.

Pranata Hukum Berbasis Kearifan... 196 
Pada awalnya ditentukan di dalam Konsideran, bagian menimbang, huruf b, Ketetapan Majelis Permusyawaratan Rakyat Sementara (MPRS) No. XX/MPRS/1966 tentang memorandum Dewan Perwakilan Rakyat Gotong Royong mengenai sumber tertib hukum Republik Indonesia dan tata urutan perundangan Republik Indonesia menyatakan bahwa untuk terwujudnya kepastian dan keserasian hukum, serta kesatuan tafsiran dan pengertian mengenai Pancasila dan pelaksanaan UUD 1945 perlu adanya perincian dan penegasan mengenai sumber hukum tertib hukum dan tata urutan peraturan perundangan Republik Indonesia. Bentuk-bentuk peraturan perundang-undangan di dalam Keputusan MPRS No. XX/MPRS/1966 adalah Undang-Undang Dasar Republik Indonesia 1945, Ketetapan Majelis Permusyawaratan Rakyat Republik Indonesia, Undang-Undang / Peraturan Pemerintah Pengganti Undang-Undang, Peraturan Pemerintah, Keputusan Presiden, Peraturanperaturan pelaksanaan lainnya, seperti Peraturan Menteri, Instruksi Menteri dan lain-lain sebagainya. Penyebutan bentuk-bentuk peraturan perundangan dalam Ketetapan Majelis Permusyawaratan Rakyat Sementara No. XX/MPRS/1966 mempunyai sifat hierarkhis, artinya peraturan perundangan yang disebut lebih dahulu mempunyai kedudukan lebih tinggi dari pada peraturan perundangan yang disebutkan sesudahnya. tidak boleh bertentangan dengan peraturan perundangan yang lebih tinggi.

Dari uraian di atas dapat diketahui bahwa puncak dari sifat hierarchis dari tata urutan peraturan perundangan di Indonesia adalah Undang-Undang Dasar 1945 yang di dalam pembukaannya terdapat Pancasila. Tata urutan peraturan perundangan berdasar Teori Jenjang (Stufenbautheorie), dalam bentuk piramida berpuncak piramida Grundnorm sebagai norma hukum tertinggi.

Perubahan pertama, ketentuan di dalam Konsideran, bagian menimbang, huruf $b$, Ketetapan Majelis Permusyawaratan Rakyat Sementara (MPRS) No. XX/MPRS/1966 tentang memorandum Dewan Perwakilan Rakyat Gotong Royong mengenai sumber tertib hukum Republik Indonesia dan tata urutan perundangan republik Indonesia, sudah dinyatakan tidak berlaku berdasarkan Ketetapan Majelis Permusyawaratan Rakyat No. I/MPR/2003. Selanjutnya Ketetapan Majelis Permusyawaratan Rakyat Sementara No. XX/MPRS/1966 tersebut diubah dengan Ketetapan Majelis Permusyawaratan Rakyat No. III Tahun 2000.

Yustisia Vol.1 No.2 Mei - Agustus 2012
Perubahan kedua,sistem perundangundagan di Indonesia tersebut diubah dengan Undang-Undang No. 10 Tahun 2004 tentang Pembentukan Peraturan Perundang-undangan, yang memiliki implikasi teoritik dan praktis terhadap ketatanegaraan Republik Indonesia. Secara formal hierarki peraturan perundangundangan ditentukan di dalam ketentuan Pasal 7 ayat (1) UU No. 10 Tahun 2005 yaitu UndangUndang Dasar Negara Republik Indonesia 1945, Undang-Undang/Peraturan Pemerintah Pengganti Undang-Undang, Peraturan Pemerintah dan Peraturan Presiden, Peraturan Daerah

Lembaga yang berwenang membuat suatu peraturan perundang - undangan disesuaikan dengan bentuk peraturan perundangundangan yang akan dibuatnya. Negara Republik Indonesia melakukan perubahan mendasar mengenai lembaga pembuat undang-undang dengan dilakukannya amandemen terhadap Undang-Undang Dasar 1945 sebagai upaya untuk mewujudkan ide hukum menjadi kenyataan. Proporsi ini berada pada tataran law making institutions dalam hal ini legilslatif dan eksekutif.Sedangkanproporsisanctioning institutions/guardian law institutions berada dalam kewenangan Mahkamah Konstitutsi. Dalam konteks ini peranan masyarakatberada dalam role occupant.

\section{Budaya Hukum Dalam Pranata Kehidupan Berbangsa dan Bernegara}

Teori budaya hukum muncul pertama kali pada masa menjelang akhir abad ke 20 atau sekitar tahun 1960 an. Budaya hukum diperkenalkan pertama kali oleh Lawrence M. Friedman (1975: 15), dengan istilah "social force" atau kekuatankekuatan sosial, yang diartikan bahwa social force as constantly at work on the law-destroying here, renewing there; inigorating here, deadening there; choosing what parts of "law" will operate, which part will not, what substitute, detours, and by passes will spring up; what changes will take place openly or secretly. For want of a better term, we can call some of these forces the legal culture. It is the element of social attitude an value.Lebih lanjut Friedman mengemukakan (1975: 193), the term legal culture has been loosly used to discribe a number of related phenomena. It refers to public knowledgeof and attitudes and behavior patterns toward the legal system. Do people feel and act as if courts are fair?

Pranata Hukum Berbasis Kearifan...

197 
When are they willing to use courts? What part of the law do they consider legitimate? What do they know about the law in general? These attitudes differ from person to person, but one can also speak of the legal culture of a country or a group, if there are patterns that distinguish it from the culture of the countries or groups...

Tipe-tipe budaya hukum, menurut Satjipto Rahardjo (2004: 79), secara garis besar ada dua, yaitu individual (sebagaikmana budaya hukum di Amerika), dan kolektif-komunal (sebagaimana budaya hukum di Jepang).Friedman, sebagaimana dikutip Soerjono Soekanto (1998: 166-167), membedakan budaya hukum ke dalam beberapa kategori, yaitu 1) budaya hukum yang berpengaruh secara positif atau negatif terhadap hukum nasional, 2) Budaya hukum internal dan budaya hukum eksternal, dan 3) Budaya hukum tradisonal dan budaya hukum modern.Mochtar Lubis (1993: 114115) mengungkapkan, sama sekali tidak ada jaminan bahwa orang yang berotak tajam dan orang yang amat pintar, otomatis juga adalah manusia yang baik, berbudi, beradab, dan berbudaya. Banyak manusia yang berotak tajam atau jenius, mempergunakan kejeniusan mereka untuk berbuat kejahatan. Lebih lanjut, dikatakannya, dan seandainya kekuasaan dipegang oleh manusia-manusia pintar demikian dan mereka tidak pula memiliki sesuatu nilai-etis, tidak berbudaya, tidak bermoral, alangkah luar biasanya bencana yang dapat ditimbulkannya bagi manusia lain atau masyarakatnya sendiri. Oleh karenanya, menurut Mochtar Lubis (1993: 15), agar seorang anak manusia menjadi manusiawi, lingkungan hidupnya perlu pula satu lingkungan yang penuh nilai manusiawi, dan masyarakatnya pun harus pula terikat untuk mendukung nilai-nilai manusiawi, dan semua ini harus tercermin dalam sistem politik masyarakat itu, dalam tingkah laku penguasa dan seluruh anggota masyarakat.

Budaya meliputi seluruh aspek kehidupan manusia yang menyangkut segi nilai-nilai, etika, moral dan peradaban. Subbudaya hukum sangat penting karena menjadi penyebab atau penentu tipetipe sikap dan perilaku hukum masyarakat (Soerjono Soekanto, 1993: 164).Hubungan antara kebudayaan dan hukum, dikemukakan oleh Koentjaraningrat (1987: 25), sebagai suatu sistem nilai budaya terdiri dari komponen-komponen yang hidup dalam alam pikiran sebagian besar masyarakat mengenai hal-hal yang harus mereka anggap amat bernilai dalam hidup. Karena itu suatu sistem nilai budaya biasanya berfungsi sebagai pedoman tertinggi bagi kekuatan

Yustisia Vol.1 No.2 Mei - Agustus 2012 manusia. Sistem tata kelakuan manusia yang tingkatannya lebih konkrit, seperti norma-norma, hukum dan aturan-aturan khusus, semua berpedoman kepada sistem nilai budaya.Law varies also with culture(Cotterrell, 1984: 14). Pada kalimat selanjutnya dengan mengutip pendapat Black (1976: 63), bahwa where culture is sparse so is law, where it is rich, law flourishes, Cotterel menjelaskan, law varies also with collective organisation in a society. The more organisational complexity and diversity, the more law. And so on.

\section{E. Pranata Hukum Berbasis Kearifan Lokal}

Satjipto Rahardjo (2004: 76-79), sejak muncul Budaya hukum, sistem hukum dipercaya dengan satu komponen yang tidak berupa peraturan formal maupun institusi-institusi, melainkan sesuatu yang lebih bersifat spiritual. Budaya hukum merupakan semacam kekuatan yang menggerakkan bekerjanya hukum. Budaya hukum berupa nilai-nilai, tradisi, dan lain-lain kekuatan spiritual yang menentukan bagaimana hukum itu dijalankan dalam masyarakat.

Dari pemikiran tersebut di atas, untuk dapat melakukan kehidupan berbangsa dan bernegara yang berbudaya setiap Warga Negaradan setiap Pelaksana Pemerintahan harusmemahami, menyadari dan menempatkan dirinya sebagai hambaTuhan Yang MahaKuasa. Dengan kata lain, kehidupan berbangsa dan bernegara harus dilandasi dengan ajaran agama. Pada dasarnya konsep dasar ajaran agama adalah budi pekerti dan tata krama. Sebagai contoh, ajaran Agama Islam adalah al-akhlaq wal adab artinya mengedepankan budi pekerti dan tata krama sebagai konsep intensitas kehidupan yaitu rahmatan lil 'alamin.

Konsep dasar kehidupan berbangsa dan bernegara bagi bangsa Indonesia yang berbudaya dilandasi dengan ketekunan melaksanakan ibadah menurut agama dan kepercayaan masing-masing itulah kepribadian bangsa Indonesia.Dengan bekal kehidupan beragama, manusia berbudaya akan selalu ingat bahwasanya perilaku nyata akan membawa konsekwensi pada pertanggung jawaban terhadap perilakunya tersebut. Oleh karenanya para pelaku yang berada pada tataran law making institutions dan sanctioning institutions/guardian law institutions harus memperhatikan hal itu supaya tidak merugikan

Pranata Hukum Berbasis Kearifan... 198 
pihak yang berada pada tataran role occupant, yaitu masyarakat.

Kepribadian berbasis kearifan lokal (Jawa) sebagai pengabdian di dalam kehidupan berbangsa dan bernegara tersebut dapat dirunut dari konsep dasar semboyan 'Bhinneka Tunggal Ika, Tan Hana Dharma Mangrwa'.Frasa ini merupakan kutipan dari sebuah buku Jawa Kuna yaitu kakawin atau Kitab Sutasoma, karangan Mpu Tantular, pada masa Kerajaan Majapahit, abad ke-14.Hanya semboyan 'Bhinneka Tunggal Ika', tercantum dalam Lambang Negara Republik Indonesia'Garuda Pancasila'. Sedangkan 'Tan Hana Dharma Mangrwa' tidak dicantumkan, padahal itu merupakan satu kalimat yang mengndung makna secara holistik

Kalimat tersebut berasal dari Pupuh 19, Gatra atau Bait ke lima, secara lengkap berbunyi sebagai berikut :

Rwāneka dhātu winuwus Buddha Wiswa,

Bhinnêki rakwa ring apan kena parwanosen, Mangkang Jinatwa kalawan Śiwatatwa tunggal,

Bhinnêka tunggal ika tan hana dharma mangrwa.

Terjemahan:

Konon Buddha dan Siwa merupakan dua zat yang berbeda.

Mereka memang berbeda, tetapi

bagaimanakah bisa dikenali?

Sebab kebenaran Jina (Buddha) dan Siwa adalah tunggal

Terpecah belahlah itu, tetapi satu jugalah itu.

Tidak ada kerancuan dalam kebenaran

Secara harfiah, pengertian 'Bhinneka Tunggal Ika' adalah 'Beraneka Satu Itu', yang bermakna meskipun berbeda-beda tetapi pada hakikatnya merupakan satu kesatuan. Semboyan ini digunakan untuk menggambarkan persatuan dan kesatuan Bangsa dan Negara Kesatuan Republik Indonesia yang terdiri atas beraneka ragam budaya, bahasa daerah, ras, suku bangsa, agama dan kepercayaan. Dengan pengertian ini diharapkan :

1. Memegang teguh prinsip Bhineka Tunggal Ika, Artinya meskipun Bangsa Indonesia mempunyai keanekaragaman latar belakang kehidupan tetapi tetap merupakan satu kesatuan yang menyatu sebagai kekuatan budaya. Semua unsur penopang kehidupan

Yustisia Vol.1 No.2 Mei - Agustus 2012 berbangsa dan bernegara, yaitu negara sebagai suatu lembaga pemerintah dan lembaga-lembaga kenegaraan, pimpinan lembaga serta pejabat negara dan warga negara merupakan sinergi yang demokratis dan mengejewantah pada profesionalisme secara proporsional menurut kedudukan, tugas dan kewajiban masing-masing.

2. Mendasarkan pengabdian di dalam kehidupan berbangsa dan bernegara pada sikap Tan Hana Darma Mangrowa, artinya tidak ada darma bakti yang mendua. Pengabdian abdi dalem berawal dari niat diri sendiri bukan paksaan, sehingga di dalam pengabdiannya tidak disertai motivasi dan pamrih yang bertentangan dan/atau merugikan eksistensi Negara Indonesia sebagai negara hukum berdasarkan pranatan dan paugeran yang telah ditetapkan di dalam peraturan perundang-undangan.

Kedua prinsip dasar tersebut,kemudian banyak dikembangkan oleh para pemimpin kerajaan ataupun para pujangga. Salah satunya oleh Pangeran Mangkubumi yang kemudian bertahta dengan gelar Sri Sultan Hamengku Buwana. Implementasi pengabdian semua unsur penopang kehidupan berbangsa dan bernegara dengan prinsip Manunggaling Kawulo Gusti, atinya manunggalnya para pemimpin negara dan seluruhnya rakyatnya, serta manunggalnya pemimpin negara sebagai hamba makhluk ciptaan Tuhan dengan Tuhannya (Jatiningrat: 2008). Istilah 'pemimpin' memfokus pada fungsi kebenaran bukan fungsi kebaikan. Implikasi sumpah jabatan kenegaraan. bukan hanya melekat pada diri pemimpin tetapi untuk semua unsur kehidupan manusia dan budaya. Eksistensi para pejabat negara dan pemerintahan serta rakyatnya merupakan bagian yang menyatu secara holistik untuk menuju pada kehidupan yang ayom, ayem tentrem, sejahtera lahir dan batin di dunia dan di akherat. Prinsip ini (Manunggaling Kawula Gusti) telah dibuktikan oleh Pangeran Mangkubumi yang berhasil mencegah intervensi dan penetrasi kekuasaan Kolonial Belanda di dalam sistem Kerajaan Mataram pada waktu itu, sehingga melahirkan Perjanjian Giyanti (Jatiningrat, 2009). Oleh karenanya di dalam kehidupan berbangsa dan bernegara, prinsip Manunggaling Kawulo Gusti tersbut diimplementasikan dengan niat :

a. Bertekad bulat secara Golong Gilig (menyatu secara bulat), sebagai suatu sinergi

Pranata Hukum Berbasis Kearifan... 
yang utuh dan kokoh, sehingga tidak mudah goyah di dalam pengabdian kepada agama, nusa, bangsa dan Negara Republik Indonesia. Prinsip ini dvisualisasikan oleh Sri Sultan Hamngku Buwana I (Pangeran Mangkubumi) dalam bentuk sebuat "Tugu" di Yogyakarta, pada awal berdirinya Karaton Nagyogyakarta Hadiningrat (Waseso Winoto: 2009)

b. Mempunyai kredo pengabdian Nyawiji (menyatu secara holistik), Greget (semangat dan prospektif), Sengguh (berkepribadian yang kuat) dan Ora Mingkuh (tidak akan lari dari tugas dan tanggung jawab), sebagai wujud jiwa Kesatria yang berbekal idealisme yang prospektif, komitmen kepribadian yang teguh dilandasi integritas moral yang berbudaya, nurani yang bersih tanpa pamrih, konsisten di dalam sikap, perkataan dan perbuatan, serta bertanggungjawab.

3. Polapikir Hamemayu Hayuning Bawono merupakan desiderata utama di dalam kehidupan berbangsa dan bernegara untuk mencapai tata kehidupan yang tata titi tentrem kartaraharja secara demokratis yang diridhoi oleh Tuhan Yang Maha Esa, berdasarkan kehidupan agama yang harmonis dan selaras dengan pelestarian dan pengembangan budaya, adat dan tradisi untuk kesejahteraan kehidupan bersama.

\section{F. Penutup}

Konsep kearifan lokal di dalam pranata kehidupan berbangsa dan bernegara seperti diuraikan di atas, apabila dipahami, dihayati dan dilaksanakan akan terwujud tujuan utamanya yaitu tata kehidupan yang harmonis dan berbudaya antara para pemimpin dan rakyatnya, serta penegakan hukum dan keadilan sehingga tercapai tata kehidupan yang sejahtera, adil dan makmur bagi seluruh bangsa Negara Republik Indonesia. Dalam tata kehidupan dan hukum modern sekarang ini, lebih didominasi oleh paham positivistik dengan berbagai kritik yang berawal dari konsistensi tekstual perundang-undangan. Oleh karenanya secara hermanutik, memerlukan penafsiran yang lebih mendasar dari latar belakang pengaturan suatu gejala hukum dan fenomena hukum yang terjadi.

Eksistensi pranata berbasis kearifan lokal menjadi sangat penting karena telah menyatu dalam tata kehidupan masyarakat. Substansinya tersirat di dalam Grundnorm Pancasila dan UUD 1945, namun di dalam peraturan perundang-undangan belum mendapat tempat yang semestinya sehingga menimbulkan perilaku yang menyimpang dari tata kehidupan berbangsa dan bernegara. Oleh karenanya Semboyan Bhinneka Tungal Ika seyogyanya dilengkapi sesuai aslinya yaitu Tan Hana Dharma Hangrowa. Para pemimpin negara bukan sekedar politicus tetapi 'negarawan' yang dapat menerapkan manunggaling kawula gusti secara golong gilig dengan rakyatnya, dan bekerja dengan nyawiji, greget, sengguh dan ora mingguh, dengan tujuan utama hamemayu hayuning bawono. 


\section{DAFTAR PUSTAKA}

Blaks. D. J., 1976, The Behavior of Law, Academic Press, London.

Cotterell, Roger, 1984, The Sosiology of Law : In Introduction, London: Butterworth \& Co. (Publishers) Ltd.

Friedmann, Wolfgang, 1953, Legal Theory, London: Stevens \& Sons, London. Diterjemahkan oleh Mohammad Arifin, 1993, Teori dan Filsafat Hukum, Telaah Kritis Atas teori-Teori Hukum, Jakarta: Raja Grafindo Persada.

Hart., H.L.A., 1972, The Concept of Law, London: Oxford University Press

Jatiningrat, K.R.T. H.,S.H., 2008, Letak Keraton Ngayogyakarta Hadiningrat, Makalah, Untuk kalangan sendiri. ,2009, Alasan Mengapa Terjadi Perjanjian Giyanti, Makalah, Untuk kalangan sendiri..

Koentjaraningrat, KebudayaanMentalitasdan Pembangunan, Cet. Ke-13, P.T. Gramedia, Jakarta, 1987.

Lawrence M. Friedman, The Legal System: A Social Science Perspective, New York :Russel Sage Foundation, 1975.

MochtarLubis, ManusiaEtisatauManusiaMahaPintar?, dalamBudaya, MasyarakatdanManusia Indonesia, Himpunan “CatatanKebudayaan" MochtarLubis di MajalahHorison, Cet. Kedua, YayasanObor Indonesia, Jakarta, 1993, hlm. 114-115.

SatjiptoRahardjo, IlmuHukum: Pencarian, PembebasandanPencerahan, Muhammadiyah University Press, Surakarta, 2004, hlm. 76-79.

SoerjonoSoekanto, et. Al. DisiplinHukumdanDisiplinSosial, Rajawali Press, Jakarta, 1998, 166-167.

Waseso Winoto, KRT., Drs. 2009, Tugu Golong Gilig, Makalah, Untuk kalangan sendiri. 